\title{
Intellectual Capital and Firm Performance across Pakistani Industries
}

\author{
Muhammad Ahmad (Corresponding author) \\ School of Economics, Finance and Banking, University Utara Malaysia \\ Sintok, Changloon 06010 Kedah, Malaysia
}

Tel: 60-111-690-2751Ｅ-mail: ahmadsefb@gmail.com

Dr. Rohani Mohd Rus

School of Economics, Finance and Banking, University Utara Malaysia

Sintok, Changloon 06010 Kedah, Malaysia

Tel: 60-194-101-666 E-mail: rohani@uum.edu.my

\begin{abstract}
Received: November 12, 2021 Accepted: November 26, 2021 Published: December 4, 2021
doi:10.5296/ber.v11i4.19132ＵRL: https://doi.org/10.5296/ber.v11i4.19132
\end{abstract}

\begin{abstract}
This study sheds light on the differences in intellectual capital (IC) efficiencies across non-financial sectors in Pakistan and determines the relationship between IC and firm performance. The study used sample of 155 non-financial firms from the manufacturing and service industries of Pakistan for the period 2009-2018. This study contributes to IC research by applying modified value-added intellectual capital (MVAIC) model with relationship to firm performance (return on assets and Tobin's Q) of Pakistani non-financial firms which was overlooked by the previous researchers. In addition, to deal with endogeneity, the dynamic panel generalized methods of moments regression is applied to test the relationship between IC and performance. Findings provide evidence that different sectors in non-financial industries manage IC components differently. IC increases both market-based performance and accounting-based performance of Pakistani firms. Among all IC components, human capital efficiency is an important determinant of firm performance. The implications can provide help managers and investors to understand the IC to increase the firm performance.
\end{abstract}

Keywords: Intellectual capital, MVAIC, Firm performance, Accounting-based performance

JEL classifications: G30; G32 


\section{Introduction}

Intellectual Capital (IC) is a valuable resource that provides competitive advantage and contributes in the firm performance (Chen et al., 2005). Firms in more than $60 \%$ of the advanced economies create value through IC resources (Vargas-Hernández \& Noruzi, 2010). However, in developing countries, the concept and application of IC are still at an early stage (Khalique et al., 2013). All of these attributes of strategic resources are also described in the IC literature. IC is an intangible strategic resource and directly related with high firm performance (Riahi-Belkaoui, 2003). This is consistent with the resource-based view where it suggests that efficient management of strategic resources like intangible assets enables firms to achieve competitive advantage and high performance (Hsu \& Wang, 2012). Either tangible or intangible, strategic resources are more valuable, unreplaceable, untransferable, inimitable therefore ensure the competitiveness and high-level performance.

Effective management of IC mitigates the gap between firm's book value and market value thus has become a key factor to create firm value (Kamukama et al., 2010) however, the value drivers of IC vary across industries (Liang et al., 2011). The literature lacks evidence for evaluation of IC performance across non-financial industries. Among a few studies, Singh and Narwal (2015) reported the difference for IC efficiencies between Indian manufacturing, service, and technology industries. In Pakistan, IC efficiencies are determined for financial sectors using VAIC (Ahmad \& Ahmed, 2016). This fact makes non-financial industries appropriate and attractive for IC research.

Taking into account the significance and necessity of IC valuation for non-financial industries, this research is beneficial through the valuation and comparison of IC components in all non-financial sectors with the motive of providing them simple method for understanding and evaluating their performance. Therefore, this study contributes to the existing literature by conducting a comparative analysis of IC performance of non-financial sectors and addresses two research issues: i) Do non-financial industries invest in IC components differently? ii) Does IC (measured by MVAIC) and its components influence both firm's market performance and financial performance?

The remaining sections of this study are categorized as follows. In section 2, literature review, IC measurement, and hypotheses development are discussed. Section 3 presents the research methodology and section 4 discusses the empirical results. Finally, section 5 concludes and provides implications of the study.

\section{Literature Review}

In the firms' success, the intellectual capital (IC) role is no less important than financial resources. Studies have shown that businesses perform sustainably when they highly invest in intellectual capital. IC increases the firms' market value and efficiency in the long term (Yalama, 2013). Firms can move the economies from the tangible assets-based economy towards an intangible assets-based economy (Fathi et al., 2013). Many scholars are in the consensus that there is no universally acceptable definition of IC (El-Tawy \& Tollington, 2012; Engström et al., 2003; Gerpott et al., 2008). 
IC scholars and practitioners deeply explored the IC components. Generally, IC is a mix of human capital, structural capital, and relational capital. Human capital is the body of knowledge owned by the organization and lives in the minds of employees (McGregor et al., 2004). In industrialized emerging economies, the value-generating competencies of a workforce are a key resource for commercial success (Morris, 2015). Khalique et al. (2013) argued that firms will face big challenges to find efficient human capital that will create structural capital and relational capital. Human capital efficiency is often found positively associated with firm performance (Lu et al., 2021; Sardo \& Serrasqueiro, 2017; Tran \& Vo, 2020).

Meanwhile, structural capital is defined as the value of knowledge that is left in firm after the employees leave (Roos et al., 1997; Wu \& Chou, 2007). It involves all the knowledge stored in the firm infrastructure such as patents, formulas, trademarks, organization procedures, reputation, and research and development (Bontis, 2001; Denicolai et al., 2015; Zéghal \& Maaloul, 2010). Relational capital includes the knowledge rooted in the relationships an organization develops with suppliers, customers, competitors, government bodies, or trade associations (Bontis, 1999; Kweh et al., 2014; Yu et al., 2015). Relational capital is also referred as customer capital (Nazari \& Herremans, 2007).

Recognition of IC in bringing competitiveness to achieve high firm performance raises the need to manage it effectively. IC measurement has remained a difficult task because of its intangible nature (Andrikopoulos, 2005; Berzkalne \& Zelgalve, 2014; Kim et al., 2009; Maditinos et al., 2011; Nazari \& Herremans, 2007). The traditional accounting-based IC measurement models focused on physical and financial assets which neglect several IC assets (Zéghal \& Maaloul, 2010). Traditional accounting-based IC measurement methods are; Economic Value Added (Stewart, 1991), Skandia Value Scheme (Edvinsson \& Malone, 1997), Calculated Intangible Value (Luthy, 1998), Intangible Asset Monitor Approach (Sveiby, 1997). Pulic (1998) introduced value-added intellectual capital (VAIC ${ }^{\mathrm{TM}}$ ) model to overcome the problems faced by traditional accounting-based methods. VAIC ${ }^{\mathrm{TM}}$ is capable to assess such efficiency in terms of the resources' ability to create firm value. According to Pulic (1998), there are two important aspects in the VAIC ${ }^{\mathrm{TM}}$ model comparative to other models. First, it is an efficient system that monitors the employees' activities towards value creation. Second, it can be applied to unlisted firms which are lack of creating market-based value through IC. Pulic (2000) argued that components of IC including human capital, structural capital and capital employed (or physical capital) generate firms' efficiency and market value. Although Balanced Scorecard Method was also introduced by Kaplan and Norton (2005) but researchers widely accepted Pulic's VAIC ${ }^{\mathrm{TM}}$.

Chan (2009) added that VAIC ${ }^{\mathrm{TM}}$ model treats the employees or human capital as significant sources of IC which is consistent with all major IC definitions. Meanwhile, Cabrita (2009) and Sydler et al. (2014) stressed that it is worthwhile to examine each component of IC, since firms can better comprehend that systematically how distinct firm's elements interact and combine in order to create wealth. Overall, Pulic's VAIC ${ }^{\mathrm{TM}}$ method is simple and straightforward to determine the IC value. It allows the stakeholders to evaluate and examine the efficiency of resources exclusive of the industry standards application (Laing et al., 2010; 
Tan et al., 2015).

The derivation of original model developed by Pulic (1998) initiate with an ability of firm to create value-added (VA). Generally, VA is the difference between the revenue and expenses, and it can be represented as;

$$
V A=O U T-I N
$$

Where, OUT (output) represents the total revenue generated from the sale of products and services. IN (input) is the sum of employee cost, depreciation, and amortization. Notably, one of the key aspects in Pulic's method is that it treats human as value creators. Thus, in this model, labor expenses (employee wages) are counted as an investment not as a cost. The result of VA shows the ability of a firm to create value which is required for the investment in resources such as financial assets, salaries, interests, dividends to investors, and taxes to the state. The more efficient human capital, structural capital, and capital employed result in higher VA. Therefore, all these resources are named as human capital efficiency (HCE), structural capital efficiency (SCE), and capital employed efficiency (CEE) (Pulic, 2000, 2004). HCE is derived by dividing VA to HC where HC involves wages including total salaries or benefits given to employees.

$$
H C E=\frac{V A}{H C}
$$

The second component SCE is derived by dividing the structural capital with value-added, where the structural capital (SC) is the result of VA minus HC of a firm.

$$
S C E=\frac{S C}{V A}
$$

The sum of both HCE and SCE is known as intellectual capital efficiency (ICE).

$$
I C E=H C E+S C E
$$

According to Pulic, human capital and structural capital cannot perform without the financial or physical capital therefore capital employed efficiency (CEE) is added in ICE. Capital employed efficiency is obtained by dividing value-added with capital employed, where, capital employed (CE) is the net book value of assets. CEE shows how much new value has been created by investing in the business (Pulic, 2000). As one of the components of VAIC ${ }^{\mathrm{TM}}$, CEE served as a pointer to value-added efficiency of capital employed (Firer \& Williams, 2003). Therefore, employment of this resource and its information in value creation is necessary (Pulic, 1998, 2008). CEE takes physical and financial capital into account to calculate the efficiency of capital employed (Hejazi et al., 2016; Kamath, 2007).

$$
C E E=\frac{V A}{C E}
$$

Overall VAIC ${ }^{\mathrm{TM}}$ is the aggregate of HCE, SCE and CEE. The complete deviation of Pulic's $\mathrm{VAIC}^{\mathrm{TM}}$ is as follows; 


$$
V A I C^{T M}=I C E+C E E
$$

Several studies adopting the original VAIC ${ }^{\mathrm{TM}}$ model found mixed results for the relationship between IC and firm performance. For example, Mehri et al. (2013) conducted a study on 92 Malaysian listed firms throughout 2006-2010 and found that HCE, SCE, CEE, and VAIC were significantly and positively related with all measures of firm performance (asset turnover, return on assets, return on equity and market-to-book ratio). In India, Singh and Narwal (2015) conducted a study on 300 listed manufacturing firms from 2003 to 2012. Using OLS regression, they found mixed results where HCE was significantly and positively related with ROA only. CEE was significantly and positively related with ROA and MB. SCE was insignificant with ROA and MB. To provide robust results Nadeem et al. (2017) conducted dynamic panel investigation on 571 Australian listed firms using generalized methods of moments (GMM). Their results revealed the significant and positive relationship between HCE, SCE, CEE and two proxies of firm performance namely ROA and ROE.

Despite wider acceptability of VAIC ${ }^{\mathrm{TM}}$ model, a few authors have also pointed out limitations regarding the VAIC ${ }^{\mathrm{TM}}$ application in IC measurement. Stahle et al. (2011) criticized the Pulic's VAIC ${ }^{\mathrm{TM}}$ by describing theoretical misperceptions and analysing calculation methods. In addition, they tested the hypothesis for correlation of Pulic's VAIC ${ }^{\mathrm{TM}}$ with market value to find the inconsistency in results with previous studies. They find that VAIC ${ }^{\mathrm{TM}}$ model focuses only on capital investment and firm's labor expense rather than IC. The critical validity problem is the "perfect superimposition" between the calculation of HCE and SCE. Generally, higher HC should lead to higher HCE value while calculations in the VAIC ${ }^{\mathrm{TM}}$ model result in lower HC and higher HCE. In calculations of VA, the amortization and depreciation are independent of VA. Calculation of SC (VA-HC) shows that value creation is created by both IC and SC variables which makes challenging to compare the capital-intensive industries or countries with capital poor ones because of differences in their cost. Broadly, according to them, Pulic's VAIC ${ }^{\mathrm{TM}}$ is just another measure of operational efficiency and does not measure IC.

Andriessen (2004) also raised similar critiques such as use of labor cost to represent human capital (HC), effect of HC and structural capital (SC) are inverse to each other and value creation may because of the synergy between IC components which is unobservable in the model. In addition, empirical results by Maditinos et al. (2011) also raised the criticism on effectiveness of VAIC ${ }^{\mathrm{TM}}$ particularly when they found relationship between HCE and performance (ROE). They raised questions regarding VAIC ${ }^{\mathrm{TM}}$ reliability: "Does the VAIC methodology properly describes the business reality (therefore, IC has no impact on market value, financial performance, etc.), or does it need improvements/adjustments in order to better mirror the business landscape?" Furthermore, they linked their questions/ criticism with the context of previous research. According to them, VAIC ${ }^{\mathrm{TM}}$ better fits in developing economies rather than developed economies because it is based on fundamental accounting measures. Therefore, emerging and developing economies provide ideal settings for its implementation. However, such economies are based on tangible assets rather than intangible assets; thus, it all provides a reason for the negative relationship between VAIC $^{\mathrm{TM}}$ and performance. Conclusively, this study declared $\mathrm{VAIC}^{\mathrm{TM}}$ as an inefficient method of IC 
measurement like other tools.

Iazzolino and Laise (2013) provided methodological and theoretical critical review on Pulic's VAIC $^{\mathrm{TM}}$ model. They stressed that accounting terms used in Pulic's model are re-interpreted relative to the Skandia Value Scheme and not related to the knowledge management. On the other side, in comparison of several IC measurement models Starovic and Marr (2003) conclude that Pulic's VAIC ${ }^{\mathrm{TM}}$ may be a combination of ideas to provide practical solution. Thus, Pulic's VAIC ${ }^{\mathrm{TM}}$ is not a final tool to measure or manage IC. Likewise, Britto et al. (2014) argued that the original VAIC ${ }^{\mathrm{TM}}$ model should be modified. Several studies suggested to consider relational capital in original VAIC ${ }^{\mathrm{TM}}$ model (Maji \& Goswami, 2016; Nazari \& Herremans, 2007; Ulum et al., 2014).

Due to the contrasting results of the studies and in line with the criticism on Pulic's VAIC ${ }^{\mathrm{TM}}$, researchers suggested to consider the modification in IC measurement to produce more precise and accurate results (Ahmad \& Ahmed, 2016; Joshi et al., 2013). Hejazi et al. (2016) argued that the combination of human capital, structural capital, and relational capital within the framework of intellectual capital becomes the key resource for value creation. Compared to VAIC $^{\mathrm{TM}}$, the MVAIC includes a new variable which is relational capital. Hence, MVAIC consider four factors which are human capital, structural capital, relational capital (Brinker, 1998; Stewart, 1997) and capital employed. Sveiby (1997) employed the term of external structure (relational capital), internal structure (structural capital), and individual competence (human capital) for all three components of IC.

Ulum et al. (2014) defined marketing expenses as proxy of relational capital and derived the relational capital efficiency (RCE) similar to calculation of SCE (marketing expenses to VA). Thus, adding relational capital in the original VAIC ${ }^{\mathrm{TM}}$ model MVAIC is derived and it is as follows;

$$
\begin{gathered}
R C E=R C / V A \\
I C E=H C E+S C E+C E E \\
M V A I C=I C E+R C E
\end{gathered}
$$

Where RCE is the relational capital efficiency and RC is proxied as marketing costs measured by selling, general and admin expanses.

Meanwhile, studies by Sydler et al. (2014) and Scafarto et al. (2016) showed that relational capital is positively associated with firm performance. Researchers agree that Pulic's VAIC ${ }^{\mathrm{TM}}$ allows comparison across industries. Amir and Lev (1996) found that the biotechnology, telecommunications, and software industries highly invest in structural capital and research and development to create IC value. For high-tech firms, human capital effect on firm performance was not direct but it indirectly affects firm values through the investment in structural capital and relational capital (Kamukama et al., 2010; Liang et al., 2011). In contrast, Nimtrakoon (2015) provided evidence that technology firms in ASEAN countries highly invest in human capital and structural capital to create overall IC value. In another study by Majumder et al. (2021), it is noted that construction sector highly invested in capital 
employed and human capital to increase firm performance. Literature review revealed the lack of research on comparison of IC efficiencies (using MVAIC) in the non-financial sector. In Pakistan, Ahmad and Ahmed (2016) measured IC performance of financial industries only thus leaving the gap to explore the IC performance in the Pakistani non-financial sector. Thus, $H 1$ is developed to compare the investment levels in IC components across non-financial industries in Pakistan

The first hypothesis is posited below:

H1. Different industries invest differently in MVAIC, HCE, SCE, RCE and CEE.

In an efficient market, efficient IC management increases market values thus IC should contribute to increase firm performance (Riahi-Belkaoui, 2003). Relative to accounting-based measure of firm performance, market-based performance captures information available to investors (Deeds et al., 1998) and reflects the market perception of the expected future performance of the companies (Dubofsky \& Varadarajan, 1987; Wisner \& Eakins, 1994). A few researchers examined the relationship for IC and firm performance using market-based and accounting-based measures of firm performance. Studies produced mixed findings.

Ahmad and Ahmed (2016) conducted study on 78 firms in Pakistani financial sector, found that HCE and SCE are significant and positively related with earning per share. SCE positively influence return on assets, negatively influence return on equity and earning per share. Considering 26 Pakistani banks, Haris et al. (2019) did not find any relationship between IC components and any measure of firm performance. Study of Castro et al. (2021) also provided different results for influence of IC and its components on return on assets, market-to-book ratio and Tobin's q of 7 Colombian banks. Except HCE, all components negatively influenced the firm performance measures.

Studies based on modified VAIC model often found no association between relational capital and firm performance (Bayraktaroglu et al., 2019; Nimtrakoon, 2015; Restuti et al., 2019; Sardo \& Serrasqueiro, 2017). For Chinese firms in the cement sector, Majumder et al. (2021) employed MVAIC method to determine the IC and firm performance relationship for the period of 2009-2018. They employed both accounting performance and market performance measures and produced mixed results based on different proxies of firm performance: HCE and CEE positively while SCE and RCE negatively influenced all measures of firm performance namely, ROA, net profit (NP) and MB. The study failed to prove relationship between MVAIC and all firm performance measures. In addition, Hussain and Mehar (2021) reported that SCE, RCE and CEE influenced ROA in manufacturing firms. Based on the mixed findings, the second hypothesis is proposed as follows:

H2.1 Human capital efficiency is significantly related with market performance.

H2.2 Structural capital efficiency is significantly related with market performance.

H2.3 Capital employed efficiency is significantly related with market performance.

H2.4 Relational capital efficiency is significantly related with market performance. 
H2.5 MVAIC is significantly related with market value.

Additionally, drawing from the previous findings for IC and accounting performance, the third hypothesis is posited as follows:

H3.1 Human capital efficiency is significantly related with accounting performance.

H3.2 Structural capital efficiency is significantly related with accounting performance.

H3.3 Capital employed efficiency is significantly related with accounting performance.

H3.4 Relational capital efficiency is significantly related with accounting performance.

H3.5 MVAIC is significantly related with accounting performance.

\section{Method}

This study used a modified VAIC approach to determine the relationship between IC and firm performance in all Pakistani non-financial firms, for the period 2007-2016. Data were collected from datastream for all the variables. Data for all financial firms and non-financial firms with missing observations (for variables of interest) were excluded which left 199 firms for the analysis. 44 firms with negative VA were removed. Based on the idea by Chu et al. (2011) that "the negative sign is carried through in all subsequent indexes, which does not generate meaningful analysis". Some other studies like Bayraktaroglu et al. (2019) and Zéghal and Maaloul (2010) have also excluded observations with negative VA. Negative VA reflect that firms are spending (input) more than their revenue (output). Finally, 155 firms from 14 manufacturing and services industries, were left for the analysis.

To measure firm performance, we choose two indicators: Tobin's Q (TQ) as a market-based performance and return on asset (ROA) as accounting-based performance. TQ is the sum of market value of equity and book value of debt to book value of assets (Chadha \& Sharma, 2015; Sherif \& Elsayed, 2016). As both types of performance measures have advantages and disadvantages, and in order to enhance the quality of any research output, this study incorporated both sets of measures. As the main objective of this study is to analyse the relationship between IC and firms' performance, we developed following regression models:

Model 1:

$$
\begin{gathered}
T Q_{i t}=\alpha_{0}+\beta_{1} H C E_{i t}+\beta_{2} S C E_{i t}+\beta_{3} R C E_{i t}+\beta_{4} C E E_{i t}+\beta_{5} L E V_{i t}+\beta_{6} S G_{i t}+\beta_{7} F S_{i t}+ \\
\beta_{8} F A_{i t}+\varepsilon_{i t}
\end{gathered}
$$

Model 2:

$$
T Q_{i t}=\alpha_{0}+\beta_{1} M V A I C_{i t}+\beta_{2} L E V_{i t}+\beta_{3} S G_{i t}+\beta_{4} F S_{i t}+\beta_{5} F A_{i t}+\varepsilon_{i t}
$$

Model 3:

$$
\begin{gathered}
R O A_{i t}=\alpha_{0}+\beta_{1} H C E_{i t}+\beta_{2} S C E_{i t}+\beta_{3} R C E_{i t}+\beta_{4} C E E_{i t}+\beta_{5} L E V_{i t}+\beta_{6} S G_{i t}+\beta_{7} F S_{i t}+ \\
\beta_{8} F A_{i t}+\varepsilon_{i t}
\end{gathered}
$$

Model 4: 


$$
R O A_{i t}=\alpha_{0}+\beta_{1} M V A I C_{i t}+\beta_{2} L E V_{i t}+\beta_{3} S G_{i t}+\beta_{4} F S_{i t}+\beta_{5} F A_{i t}+\varepsilon_{i t}
$$

Where TQ is Tobin's Q and ROA is return on assets as proxies of firms' performance respectively. Three control variables namely, leverage (LEV), sales growth (SG), and firm size (FS) are added in the empirical model. LEV is the ratio total debt divided by total equity and SG is the dividing the difference between current year's sales and previous year's sales by previous year's sales. FS is calculated natural logarithm of firm sales. FA is defined as total years since listing of firm. Table 1 summarizes measurement of all the variables.

\section{Results}

Table 3 provides information on descriptive statistics, including the observations, mean, minimum, maximum, and standard deviation of all variables. The mean value of TQ variable 1.167 indicate that Pakistani firms' average market value is about 1 time greater than their book value. Relatively, a low mean value of ROA (0.071) implies that firms faced challenges to make profit during the study period. For independent variables, the mean value of MVAIC is 6.514 reveals that sampled firms, on average, created PKR 6.514 value against every PKR 1.00. Among all IC components HCE is strong component in creating IC value. The mean value of HCE is 5.017 compared to the 0.477 (CEE), 0.757 (SCE), and 0.263 (RCE). This findings support the previous studies that human capital is a significant driver to create IC value in developing economies compared to other components (Majumder et al., 2021; Nimtrakoon, 2015).

Table 1. Variables Measurement

\begin{tabular}{|c|c|c|}
\hline Variables & Labels & Measurements \\
\hline \multicolumn{3}{|l|}{ Dependent Variable } \\
\hline Tobin's Q & TQ & $\frac{\text { Market value of equity }+ \text { book value of debt }}{\text { Book value of assets }}$ \\
\hline Return on asset & ROA & $\frac{\text { Net profit }}{\text { Total assets }}$ \\
\hline \multicolumn{3}{|l|}{ Independent Variables } \\
\hline Human Capital Efficiency & HCE & $\begin{array}{l}\text { VA/ HC } \\
\text { VA= Value Added (Sales revenue-Cost of goods sold) } \\
\text { HC=Human Capital (Total salaries, wages, and } \\
\text { benefits given to employees by a firm) }\end{array}$ \\
\hline Structural Capital Efficiency & SCE & $\begin{array}{l}\text { SC/VA } \\
\text { SC= Structural Capital (Organization policies, } \\
\text { patents, brand names) }\end{array}$ \\
\hline Rational Capital Efficiency & RCE & $\begin{array}{l}\mathrm{RC} / \mathrm{VA} \\
\mathrm{RC}=\text { Relational capital (Selling, general and } \\
\text { administrative expenses) }^{1}\end{array}$ \\
\hline Capital Employed Efficiency & CEE & $\begin{array}{l}\text { VA/ CE } \\
\mathrm{CE}=\text { Capital Employed (Book value of firm's physical } \\
\text { assets and financial assets) }\end{array}$ \\
\hline $\begin{array}{l}\text { Modified Value-Added } \\
\text { Intellectual Capital }\end{array}$ & MVAIC & $\mathrm{MVAIC}=\mathrm{HCE}+\mathrm{SCE}+\mathrm{CEE}+\mathrm{RCE}$ \\
\hline Control Variables & & \\
\hline
\end{tabular}

\footnotetext{
${ }^{1}$ Datastream field 01101 defines selling general and administrative expenses includes marketing and advertising expenses. Selection of this measure is consistent with previous modified VAIC studies.
} 


\begin{tabular}{|l|l|l|}
\hline Leverage & LEV & $\frac{\text { Total Debt }}{\text { Total Equity }}$ \\
\hline Sales Growth & SG & $\frac{\text { Current year's Sales - previous year's sales }}{\text { Previous year sales }}$ \\
\hline Firm Size & FS & Natural logarithm of firm sales \\
\hline Firm Age & FA & Total years since listing of firm \\
\hline
\end{tabular}

Table 2. Descriptive statistics

\begin{tabular}{|l|c|c|c|c|c|}
\hline Variable & Obs. & Mean & Min & Max & Std. Dev \\
\hline TQ & 1550 & 1.167 & -13.748 & 10.250 & 1.019 \\
\hline ROA & 1550 & 0.071 & -0.247 & 0.446 & 0.085 \\
\hline HCE & 1550 & 5.017 & -0.767 & 25.486 & 3.553 \\
\hline SCE & 1550 & 0.757 & -0.138 & 4.189 & 0.207 \\
\hline RCE & 1550 & 0.263 & -2.470 & 2.274 & 0.218 \\
\hline CEE & 1550 & 0.477 & -15.893 & 30.532 & 1.139 \\
\hline MVAIC & 1550 & 6.514 & -10.325 & 36.721 & 3.800 \\
\hline LEV & 1550 & 1.183 & -8.766 & 15.704 & 1.572 \\
\hline SG & 1550 & 0.149 & -0.910 & 15.476 & 0.560 \\
\hline FS & 1550 & 15.662 & 11.063 & 20.895 & 1.431 \\
\hline FA & 1550 & 16.319 & 1.000 & 28.000 & 4.760 \\
\hline
\end{tabular}

Three components HCE, SCE and RCE represent the value created by investment on employees' skills and knowledge, organizations' structure and relational networks which explains their intangible nature. CEE is the financial and physical capital. Notably, the sum of mean values of HCE, SCE, and RCE is higher than mean of CEE (0.477) which suggests that Pakistani firms are creating more IC value through intangible components instead from tangible components i.e., CEE. This result is consistent with the findings that firms operating in less developed economies create more value via intangible assets rather than physical capital (Majumder et al., 2021; Pulic, 2004; Zéghal \& Maaloul, 2010). Additionally, Table 2 reveals descriptive statistics of four control variables leverage (LEV), sales growth (SG), firm size (FS), firm age (FA). The higher mean value of leverage mean shows that Pakistani firms use $118 \%$ of debt financing. Sales growth, on average is very low with mean value of 0.149 .

To estimate the IC and firm performance relationship, we performed some basic diagnostic test. First, we performed Pearson pairwise correlation analysis. According to Kennedy (2008), multicollinearity exist between two variables when the correlation coefficient is greater than 0.70. Results in table 3 reveal that MVAIC and HCE are highly correlated. Xu and Li (2020) also reported high correlation between MVAIC and HCE for Chinese firms. MVAIC and HCE are not estimated in the same equation therefore multicollinearity cannot affect our results. Table 3 reveals that all IC components are significantly correlated with ROA. HCE has no significant correlation with TQ. Relatively CEE is strongly correlated with TQ by coefficient of 0.445 implying the significance of financial capital in improving firm's market value. Further, we also performed variance inflation factor (VIF) to identify the multicollinearity. Un-tabulated results show the highest VIF 1.21, which is less than 10 


\section{$\triangle$ Macrothink}

suggesting the absence of multicollinearity in our dataset (Wooldridge, 2015).

Table 3. Correlation matrix

\begin{tabular}{|l|l|l|l|l|l|l|l|l|l|l|l|}
\hline & TQ & ROA & HCE & SCE & CEE & RCE & MVAIC & LEV & SG & FS & FA \\
\hline TQ & 1 & & & & & & & & & & \\
\hline ROA & 0.039 & 1 & & & & & & & & & \\
\hline & 0.130 & & & & & & & & & & \\
\hline HCE & -0.007 & $0.218^{*}$ & 1 & & & & & & & & \\
\hline & 0.781 & 0.000 & & & & & & & & & \\
\hline SCE & $-0.284^{*}$ & $0.265^{*}$ & $0.427^{*}$ & 1 & & & & & & & \\
\hline & 0.000 & 0.000 & 0.000 & & & & & & & & \\
\hline CEE & $0.445^{*}$ & $0.147^{*}$ & 0.019 & $-0.235^{*}$ & 1 & & & & & & \\
\hline & 0.000 & 0.000 & 0.462 & 0.000 & & & & & & & \\
\hline RCE & $-0.106^{*}$ & $-0.191^{*}$ & $-0.133^{*}$ & $-0.211^{*}$ & -0.029 & 1 & & & & & \\
\hline & 0.000 & 0.000 & 0.000 & 0.000 & 0.263 & & & & & & \\
\hline MVAIC & $0.106^{*}$ & $0.252^{*}$ & $0.956^{*}$ & $0.371^{*}$ & $0.303^{*}$ & $-0.087^{*}$ & 1 & & & & \\
\hline & 0.000 & 0.000 & 0.000 & 0.000 & 0.000 & 0.001 & & & & & \\
\hline LEV & 0.049 & $-0.311^{*}$ & 0.003 & 0.003 & -0.040 & 0.031 & -0.007 & 1 & & & \\
\hline & 0.055 & 0.000 & 0.893 & 0.919 & 0.119 & 0.219 & 0.791 & & & & \\
\hline SG & 0.002 & $0.051^{*}$ & $0.073^{*}$ & $0.100^{*}$ & $0.359^{*}$ & $-0.073^{*}$ & $0.178^{*}$ & 0.049 & 1 & & \\
\hline & 0.930 & 0.046 & 0.004 & 0.000 & 0.000 & 0.004 & 0.000 & 0.053 & & & \\
\hline FS & $-0.113^{*}$ & $0.241^{*}$ & $0.216^{*}$ & $0.243^{*}$ & -0.008 & $-0.119^{*}$ & $0.2061^{*}$ & -0.042 & 0.035 & 1 & \\
\hline & 0.000 & 0.000 & 0.000 & 0.000 & 0.759 & 0.000 & 0.000 & 0.096 & 0.163 & & \\
\hline FA & -0.025 & 0.036 & $-0.164^{*}$ & $-0.101^{*}$ & -0.013 & $0.126^{*}$ & $-0.155^{*}$ & $-0.164^{*}$ & $-0.088^{*}$ & $0.215^{*}$ & 1 \\
\hline & 0.331 & 0.152 & 0.000 & 0.000 & 0.600 & 0.000 & 0.000 & 0.000 & 0.001 & 0.000 & \\
\hline
\end{tabular}

As previously stated, there are three main hypotheses developed. The first hypothesis is concerned with comparison for IC efficiencies i.e., MVAIC, HCE, SCE, and RCE across non-financial industries. The second hypothesis is to investigate the relationships between IC and market-based performance. The last hypothesis is to examine the relationships between IC and financial performance. All hypothesis tests are described as follows.

Prior studies indicated that intellectual capital efficiency is not the same across different industries (Clarke et al., 2011; Joshi et al., 2013; Singh \& Narwal, 2015). To test the first hypothesis non-parametric Kruskal-Wallis one-way ANOVA test is applied. This test compares the differences among the mean ranks in order to evaluate whether the differences among the groups are statistically significant (Siegel, 1988). The K-W statistics provided by the Kruskal-Wallis test indicate that among all groups, one group is significantly different from one of the other groups. Table 4 demonstrates the results for difference for IC across industries.

In table 4, industries are ordered based on MVAIC mean ranks. Higher mean ranks in industries imply that firms in these industries tend to generate more IC value compared to those with lower mean ranks. The K-W statistics in Table 4 prove that the investment levels in IC components (HCE, SCE, RCE, and CEE) and MVAIC are significantly different among industries. It is noticed that non-financial sectors create IC efficiency through different levels of investment in IC components. Six industries; i) food products, ii) manufacturing, iii) chemicals, chemical products \& pharmaceuticals, iv) mineral products, v) information and 


\section{Mll Macrothink}

Business and Economic Research ISSN 2162-4860 2021, Vol. 11, No. 4

communication services and vi) paper, paper board and products highly invest in RCE relative to other IC components to create IC value. Four industries; i) motor vehicles, trailer and auto-parts, ii) electrical machinery and apparatus, iii) textiles and iv) other services sectors highly invest in CEE to create IC value. Cement and sugar industries invest in HCE while fuel and energy, coke and refined petroleum products invest in SCE to create overall IC value. These findings indicate that Pakistani industries invest in IC components differently in order to create IC value thus, supporting research hypothesis 1 .

Table 4. Kruskal-Wallis ANOVA Test for industry mean ranks for IC and components

\begin{tabular}{|c|c|c|c|c|c|c|c|}
\hline No. & Sectors & $\mathbf{N}$ & MVAIC & HCE & SCE & RCE & CEE \\
\hline 1 & Food Products & 100 & 1106.68 & 1051.75 & 929.13 & 1164.18 & 1107.62 \\
\hline 2 & Cement & 100 & 1105.02 & 1114.11 & 1009.26 & 541.21 & 757.51 \\
\hline 3 & Fuel \& Energy & 70 & 1089.01 & 1131.10 & 1272.74 & 168.30 & 592.96 \\
\hline 4 & $\begin{array}{l}\text { Coke and Refined } \\
\text { Petroleum Products }\end{array}$ & 50 & 893.58 & 906.30 & 1285.22 & 562.78 & 674.18 \\
\hline 5 & Sugar & 140 & 834.84 & 854.68 & 811.56 & 693.84 & 667.79 \\
\hline 6 & Manufacturing & 130 & 794.85 & 786.70 & 803.28 & 958.86 & 769.29 \\
\hline 7 & $\begin{array}{l}\text { Chemicals, } \\
\text { Chemical Products } \\
\& \text { Pharmaceuticals }\end{array}$ & 260 & 773.03 & 727.23 & 703.34 & 1041.79 & 952.45 \\
\hline 8 & Mineral Products & 30 & 759.93 & 689.47 & 672.30 & 1026.17 & 837.93 \\
\hline 9 & $\begin{array}{l}\text { Information and } \\
\text { Communication } \\
\text { Services }\end{array}$ & 30 & 754.47 & 816.50 & 820.87 & 955.73 & 620.23 \\
\hline 10 & $\begin{array}{lr}\text { Motor } & \text { Vehicles, } \\
\text { Trailers } & \text { and } \\
\text { Auto-parts } & \\
\end{array}$ & 160 & 715.44 & 727.26 & 673.92 & 754.29 & 825.85 \\
\hline 11 & $\begin{array}{l}\text { Electrical Machinery } \\
\text { and Apparatus }\end{array}$ & 40 & 665.80 & 688.10 & 602.10 & 1079.15 & 424.60 \\
\hline 12 & Textiles & 390 & 596.01 & 613.28 & 662.92 & 631.59 & 724.48 \\
\hline 13 & $\begin{array}{l}\text { Paper, Paperboard } \\
\text { and Products }\end{array}$ & 30 & 400.67 & 469.47 & 406.17 & 552.17 & 252.50 \\
\hline 14 & Other Services & 20 & 387.45 & 380.70 & 324.50 & 635.75 & 808.75 \\
\hline & & 1550 & $\begin{array}{l}\text { K-W Stat. } \\
253.658 * * *\end{array}$ & $\begin{array}{l}\text { K-W Stat. } \\
236.822 * * *\end{array}$ & $\begin{array}{l}\text { K-W Stat. } \\
280.0126^{* * *}\end{array}$ & $\begin{array}{l}\text { K-W Stat. } \\
444.207 * * *\end{array}$ & $\begin{array}{l}\text { K-W Stat. } \\
195.134 * * *\end{array}$ \\
\hline
\end{tabular}

To investigate the relationship between IC and firm performance, all models are estimated using dynamic panel generalized methods of moments (GMM). The dynamic panel technique controls the necessary firm-specific fixed effects which may explain the IC and firm performance. Moreover, unlike the previous cross-country or cross-firm studies, the GMM controls for the potential endogeneity of independent variables. This weakness may produce the biased standard errors and coefficient estimates which possibly produce inaccurate. Unlike traditional OLS, fixed effect and random effect estimations, GMM estimator uses firm's historical values as valid instruments to account for endogeneity (Wintoki et al., 2012). In estimation, the lagged value of dependent variables is treated as endogenous.

In addition, the dynamic panel GMM estimator developed by Arellano and Bond (1991) solve the econometric problems such as solving autocorrelation and heteroscedasticity through 
differencing, thus produce consistent results (Baltagi, 2008). The Hansen (1982) J test assesses the instruments' validity and confirms absence of first-order autocorrelation. According to the null hypothesis, the over-identifying instruments are uncorrelated with the error term. The previous studies (Nadeem et al. (2017) and Tran and Vo (2020)) also used dynamic GMM for IC and firm performance relationship. Table 6 presents the results of dynamic panel GMM estimations for four models.

In table 6 , the results of Hansen $\mathbf{J}$ test and autocorrelation test indicate that instruments used in the estimations are valid thus, the results of the difference GMM estimator are robust to interpret our empirical results. The positive and significant lagged values of dependent variables (for all models) prove the dynamic relationship between the current year's performance and past year's performance.

Table 6. Dynamic panel GMM estimation results

\begin{tabular}{|c|c|c|c|c|}
\hline & \multicolumn{2}{|c|}{ Dependent variable: TQ } & \multicolumn{2}{|c|}{ Dependent variable: ROA } \\
\hline & $\begin{array}{l}\text { Model } 1 \\
H 2.1-H 2.4\end{array}$ & $\begin{array}{l}\text { Model } 2 \\
\text { H2.5 }\end{array}$ & $\begin{array}{l}\text { Model 3 } \\
\text { H3.1-H3.4 }\end{array}$ & $\begin{array}{l}\text { Model } 4 \\
\text { H3.5 }\end{array}$ \\
\hline Variable & Coeff. (p) & Coeff. (p) & Coeff. (p) & Coeff. (p) \\
\hline Lag & $\begin{array}{l}0.189 * * * \\
(0.000)\end{array}$ & $\begin{array}{l}0.138 * * * \\
(0.000)\end{array}$ & $\begin{array}{l}0.412 * * * \\
(0.000)\end{array}$ & $\begin{array}{l}0.454 * * * \\
(0.000)\end{array}$ \\
\hline HCE & $\begin{array}{l}0.019 * * * \\
(0.016)\end{array}$ & - & $\begin{array}{l}0.102 * * * \\
(0.006)\end{array}$ & - \\
\hline SCE & $\begin{array}{l}-1.752 * * * \\
(0.000)\end{array}$ & - & $\begin{array}{l}-0.659 \\
(0.105)\end{array}$ & - \\
\hline RCE & $\begin{array}{l}-2.178^{* * * *} \\
(0.000)\end{array}$ & - & $\begin{array}{l}2.302 * * * \\
(0.000)\end{array}$ & - \\
\hline CEE & $\begin{array}{l}0.400 * * * \\
(0.000)\end{array}$ & - & $\begin{array}{l}-0.396 * * * \\
(0.000)\end{array}$ & - \\
\hline MVAIC & - & $\begin{array}{l}0.155^{* * * *} \\
(0.000)\end{array}$ & - & $\begin{array}{l}0.050 * * * \\
(0.000)\end{array}$ \\
\hline LEV & $\begin{array}{l}0.187 * * \\
(0.039) \\
\end{array}$ & $\begin{array}{l}0.949 * * * \\
(0.000)\end{array}$ & $\begin{array}{l}0.180 * * \\
(0.038) \\
\end{array}$ & $\begin{array}{l}0.102 * * * \\
(0.000)\end{array}$ \\
\hline SG & $\begin{array}{l}-0.274 * * * \\
(0.000)\end{array}$ & $\begin{array}{l}0.488^{* *} \\
(0.024) \\
\end{array}$ & $\begin{array}{l}0.937 * * * \\
(0.000)\end{array}$ & $\begin{array}{l}0.406 * * * \\
(0.000)\end{array}$ \\
\hline FS & $\begin{array}{l}-0.043 \\
(0.621)\end{array}$ & $\begin{array}{l}0.049 \\
(0.791) \\
\end{array}$ & $\begin{array}{l}-0.157 \\
(0.353) \\
\end{array}$ & $\begin{array}{l}0.008 \\
(0.887) \\
\end{array}$ \\
\hline FA & $\begin{array}{l}-0.002 \\
(0.891) \\
\end{array}$ & $\begin{array}{l}0.136 * * * \\
(0.000)\end{array}$ & $\begin{array}{l}0.1567 * * \\
(0.045) \\
\end{array}$ & $\begin{array}{l}0.019 * * * \\
(0.006)\end{array}$ \\
\hline Hansen stat. $(p)$ & 0.430 & 0.661 & 0.644 & 0.219 \\
\hline $2^{\text {nd }}$ order serial correlation $(p)$ & 0.263 & 0.773 & 0.763 & 0.995 \\
\hline Instruments & 43 & 40 & 43 & 40 \\
\hline
\end{tabular}

Notes: Terms are defined as Coeff., coefficient; Lag, lagged firm performance, TQ, Tobin's Q; ROA, return on asset; HCE, human capital efficiency; SCE, structural capital efficiency; RCE, relational capital efficiency; CEE, capital employed efficiency; MVAIC, modified value-added intellectual capital; LEV, leverage, SG, sales growth; FS, firm size; FA, firm age; Constant, constant variable. For Hansen stat and $2^{\text {nd }}$ order serial correlation, P-values are given. With coefficients, values in parenthesis are $p$ values. $* * *$ represents significance at $1 \%$, $* *$ significance at $5 \%, *$ significance at $10 \%$. 


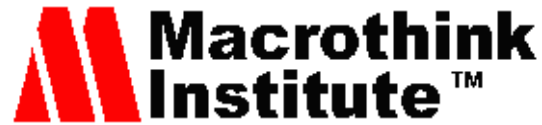

Business and Economic Research ISSN 2162-4860

2021, Vol. 11, No. 4

Model 1 and model 2 show the mixed results for relationship between IC components and market value. In model 1, HCE, SCE, RCE and CEE are significantly related with TQ at 1 percent thus supporting hypothesis H2.1 to H2.5. Among all four components, the CEE (coeff. 0.400) is strongly and positively related with TQ followed by HCE (coeff. 0.019) which is consistent with the findings of Nimtrakoon (2015). This implies that financial capital is more important than other IC components. However, SCE and RCE negatively influence TQ implying that a 1 percent decrease in SCE and RCE is associated with 1.752 percent and 2.178 percent increase in firms' market-based performance respectively. This result is consistent with the findings of Gigante (2013), Buallay (2017) and Sardo and Serrasqueiro (2017). This indicates that in Pakistani firms the structural capital and relational capital is effective. This is because firms are not making investment decisions based on the stock price but they examine the present value of expected profits generated from the investment in structural capital. In control variables, LEV is significantly and positively while SG is significantly and negatively related with TQ. In model 2 , MVAIC shows the positive impact on TQ suggesting that overall IC management increases the firms' market value. This result supports the resource-based view and support findings by previous empirical studies (Nadeem et al., 2017; Sardo \& Serrasqueiro, 2017). In control variables, LEV, SG and FA are significantly and positively related with TQ.

In Model 3, with ROA, coefficient of HCE remained positive. Coefficient of SCE remained negative (-0.659) and weak as significant at 10 percent. Coefficient of RCE changed to positive (2.302) and coefficient of CEE changed to negative (-0.496). Influence of RCE is stronger among all IC components. For individual components of IC, our GMM results partially contrast with the findings of Nadeem et al. (2017) where they find positive association between SCE, CEE and ROA. In control variables, LEV and SG are significantly and positively related with ROA while FA is significantly and negatively related with ROA. In model 4, the MVAIC shows significant positive impact on ROA. However, the MVAIC coefficient size is smaller (0.050) than model 2 (0.155) which indicates that IC has stronger influence to increase firm's market value than accounting-based performance. In control variables, LEV, SG and FA are significantly and positively related with ROA. Overall findings imply that IC increases performance of Pakistani firms and among all components human capital has played significant role.

\section{Discussion}

Intellectual capital efficiency derives from the investment in four components (human capital efficiency, structural capital efficiency, relational capital efficiency and capital employed efficiency). Investment in IC components varies across industries. This study is among the first to compare the IC efficiencies across 14 non-financial industries through Kruskal-Wallis ANOVA test. Findings suggest that all 14 industries invest in IC components differently to create IC value. Six industries invest higher in relational capital, four industries invest higher in physical capital. Only four industries highly invest in human capital and structural capital.

Since the relational capital is among the basic components of intellectual capital (Sveiby, 1997), this study modified the existing VAIC $^{\mathrm{TM}}$ model and added relational capital. 
Additionally, the modified value-added intellectual capital (MVAIC) is adopted with firms' market-based performance (TQ) and traditional accounting-based performance (ROA) which is not tested by researchers using Pakistani data. The relationship of firm performance with human capital efficiency, structural capital efficiency, relational capital efficiency, capital employed efficiency and MVAIC is analysed through the difference generalized methods of movement (GMM) method for listed Pakistani non-financial firms from 2009 to 2018.

Findings revealed that IC is an important determinant and play strong role in increasing both market-based performance and accounting-based performance of Pakistani firms. However, the influence of individual IC components on different measures of performance. Structural capital efficiency and relational capital efficiency significantly and negatively influence the TQ indicating that firms are not taking efficiently managing their networks. Our evidence also support the facts reported by World Intellectual Property Organization (WIPO) that Pakistani firms rank lower because of poor management of intellectual property rights (WIPO, 2016). The significant positive influence of human capital efficiency and capital employed efficiency on TQ implies that firms which efficiently utilise physical capital as well as skills and knowledge of its people experience the increase in market performance. On the other hand, significant negative influence of capital employed efficiency and significant positive influence of relational capital efficiency and human capital employed efficiency on ROA suggest that skilled and knowledge of people along with good customer relationships leads to increased accounting-based firm performance. Among all IC components, human capital efficiency is a strong determinant of performance in Pakistani non-financial firms. Significant and positively impact of MVAIC on firm performance suggest that non-financial firms must focus on IC if they wish to improve their performance.

This study is among the first in Pakistan that adopted MVAIC model to compare the IC efficiencies across all non-financial sectors and find the influence of IC on market-based performance and accounting-based performance. These findings leave several practical implications for the policymakers and finance managers to understand and increase the investment in IC components which would increase the business performance of Pakistani non-financial firms. Consideration of IC as an important factor in enhancing firm performance will help to develop further business strategies. Pakistani firms might need high investment in human capital, since higher investment in employees would create increased knowledge assets to the firm and therefore greater firm performance. The results of the study can help industrial regulators to critically evaluate IC and its components to increase performance. Moreover, this research is important for CEOs, shareholders and financial managers to obtain information about IC.

\section{References}

Ahmad, M., \& Ahmed, N. (2016). Testing the relationship between intellectual capital and a firm's performance: an empirical investigation regarding financial industries of Pakistan. International Journal of Learning and Intellectual Capital, 13(2-3), 250-272.

https://doi.org/10.1504/IJLIC.2016.075691

Andriessen, D. (2004). Reconciling the rigor-relevance dilemma in intellectual capital 
research. The Learning Organization, 11(4/5), 393-401.

https://doi.org/10.1108/09696470410538288

Andrikopoulos, A. (2005). The real-options approach to intellectual capital analysis: a critique. Knowledge and Process Management, 12(3), 217-224.

https://doi.org/10.1002/kpm.230

Arellano, M., \& Bond, S. (1991). Some tests of specification for panel data: Monte Carlo evidence and an application to employment equations. The Review of Economic Studies, 58(2), 277-297. https://doi.org/10.2307/2297968

Baltagi, B. (2008). Econometric analysis of panel data: John Wiley \& Sons.

Bayraktaroglu, A. E., Calisir, F., \& Baskak, M. (2019). Intellectual capital and firm performance: an extended VAIC model. Journal of Intellectual Capital, 20(3), 406-425. https://doi.org/10.1108/JIC-12-2017-0184

Berzkalne, I., \& Zelgalve, E. (2014). Intellectual capital and company value. Procedia-Social and Behavioral Sciences, 110, 887-896. https://doi.org/10.1016/j.sbspro.2013.12.934

Bontis, N. (1999). Managing organisational knowledge by diagnosing intellectual capital: framing and advancing the state of the field. International Journal of technology management, 18(5-8), 433-462. https://doi.org/10.1504/IJTM.1999.002780

Bontis, N. (2001). Assessing knowledge assets: a review of the models used to measure intellectual capital. International Journal of Management Reviews, 3(1), 41-60.

https://doi.org/10.1111/1468-2370.00053

Brinker, B. (1998). Intellectual capital: tomorrow's assets, today's challenge. [Online] Available: http://www/cpavision.org/vision/wpaper0b.cfm.

Britto, D. P., Monetti, E., \& Jr, J. D. R. L. (2014). Intellectual capital in tangible intensive firms: the case of Brazilian real estate companies. Journal of Intellectual Capital, 15(2), 333-348. https://doi.org/10.1108/JIC-10-2013-0108

Buallay, A. M. (2017). The relationship between intellectual capital and firm performance. Corporate Governance Organizational Behavior Review, 1(1), 32-41.

https://doi.org/10.22495/cgobr_v1_i1_p4

Cabrita, M. D. R. (2009). Intellectual capital: a phenomenon of interrelationships. International Journal of Business and Systems Research, 3(2), 229-256.

https://doi.org/10.1504/IJBSR.2009.024864

Castro, J. P. G., Ramírez, D. F. D., \& Escobar, J. M. (2021). The relationship between intellectual capital and financial performance in Colombian listed banking entities. Asia Pacific Management Review. https://doi.org/10.1016/j.apmrv.2021.03.002

Chadha, S., \& Sharma, A. K. (2015). Capital structure and firm performance: Empirical evidence from India. Vision, 19(4), 295-302. https://doi.org/10.1177/0972262915610852 


\section{Macrothink

Chan, H. K. (2009). Impact of intellectual capital on organisational performance: An empirical study of companies in the Hang Seng Index (Part 1). The Learning Organization, 16(1), 4-21. https://doi.org/10.1108/09696470910927641

Chen, M. C., Cheng, S. J., \& Hwang, Y. (2005). An empirical investigation of the relationship between intellectual capital and firms' market value and financial performance. Journal of Intellectual Capital, 6(2), 159-176. https://doi.org/10.1108/14691930510592771

Chu, S. K. W., Hang Chan, K., \& Wu, W. W. (2011). Charting intellectual capital performance of the gateway to China. Journal of Intellectual Capital, 12(2), 249-276.

https://doi.org/10.1108/14691931111123412

Clarke, M., Seng, D., \& Whiting, R. H. (2011). Intellectual capital and firm performance in Australia. Journal of Intellectual Capital, 12(4), 505-530.

https://doi.org/10.1108/14691931111181706

Deeds, D. L., DeCarolis, D., \& Coombs, J. E. (1998). Firm-specific resources and wealth creation in high-technology ventures: Evidence from newly public biotechnology firms. Entrepreneurship Theory and Practice, 22(3), 55-73.

https://doi.org/10.1177/104225879802200303

Denicolai, S., Ramusino, E. C., \& Sotti, F. (2015). The impact of intangibles on firm growth. Technology Analysis \& Strategic Management, 27(2), 219-236.

https://doi.org/10.1080/09537325.2014.959484

Dubofsky, P., \& Varadarajan, P. R. (1987). Diversification and measures of performance: Additional empirical evidence. Academy of Management Journal, 30(3), 597-608. https://doi.org/10.5465/256018

Edvinsson, L., \& Malone, M. S. (1997). Intellectual capital: Realizing your company's true value by finding its hidden brainpower. NY: Harper Collins.

El-Tawy, N., \& Tollington, T. (2012). Intellectual capital: literature review. International Journal of Learning and Intellectual Capital, 9(3), 241-259.

https://doi.org/10.1504/IJLIC.2012.047286

Engström, T. E., Westnes, P., \& Furdal Westnes, S. (2003). Evaluating intellectual capital in the hotel industry. Journal of Intellectual Capital, 4(3), 287-303.

https://doi.org/10.1108/14691930310487761

Fathi, S., Farahmand, S., \& Khorasani, M. (2013). Impact of intellectual capital on financial performance. International Journal of Academic Research in Economics and Management Sciences, 2(1), 6-17.

Firer, S., \& Williams, S. M. (2003). Intellectual capital and traditional measures of corporate performance. Journal of Intellectual Capital, 4(3), 348-360.

https://doi.org/10.1108/14691930310487806

Gerpott, T. J., Thomas, S. E., \& Hoffmann, A. P. (2008). Intangible asset disclosure in the 
telecommunications industry. Journal of Intellectual Capital, 9(1), 37-61.

https://doi.org/10.1108/14691930810845795

Gigante, G. (2013). Intellectual Capital and Bank Performance in Europe. Accounting and Finance Research, 2(4), 120-129. https://doi.org/10.5430/afr.v2n4p120

Hansen, L. P. (1982). Large sample properties of generalized method of moments estimators. Econometrica: Journal of the Econometric Society, 1029-1054.

https://doi.org/10.2307/1912775

Haris, M., Yao, H., Tariq, G., Malik, A., Javaid, H. M. J. J. o. R., \& Management, F. (2019). Intellectual capital performance and profitability of banks: Evidence from Pakistan. 12(2), 56. https://doi.org/10.3390/jrfm12020056

Hejazi, R., Ghanbari, M., \& Alipour, M. (2016). Intellectual, Human and Structural Capital Effects on Firm Performance as Measured by Tobin's Q. Knowledge and Process Management, 23(4), 259-273. https://doi.org/10.1002/kpm.1529

Hsu, L. C., \& Wang, C. H. (2012). Clarifying the effect of intellectual capital on performance: the mediating role of dynamic capability. British Journal of Management, 23(2), 179-205. https://doi.org/10.1111/j.1467-8551.2010.00718.x

Hussain, F., \& Mehar, A. K. (2021). Intellectual Capital, Political Uncertainty and Firm Performance: Evidence from Pakistan. Journal of Business Social Review in Emerging Economies, 7(2), 265-278. https://doi.org/10.26710/jbsee.v7i2.1645

Iazzolino, G., \& Laise, D. (2013). Value added intellectual coefficient (VAIC) A methodological and critical review. Journal of Intellectual Capital, 14(4), 547-563. https://doi.org/10.1108/JIC-12-2012-0107

Joshi, M., Cahill, D., Sidhu, J., \& Kansal, M. (2013). Intellectual capital and financial performance: an evaluation of the Australian financial sector. Journal of Intellectual Capital, 14(2), 264-285. https://doi.org/10.1108/14691931311323887

Kamath, G. B. (2007). The intellectual capital performance of the Indian banking sector. Journal of Intellectual Capital, 8(1), 96-123. https://doi.org/10.1108/14691930710715088

Kamukama, N., Ahiauzu, A., \& Ntayi, J. M. (2010). Intellectual capital and performance: testing interaction effects. Journal of Intellectual Capital, 554-574.

https://doi.org/10.1108/14691931011085687

Kaplan, R. S., \& Norton, D. P. (2005). The balanced scorecard: measures that drive performance. Harvard business review, 83(7), 172-180.

Khalique, M., Shaari, J. A. N. B., \& Isa, A. H. B. M. (2013). The road to the development of intellectual capital theory. International Journal of Learning and Intellectual Capital, 10(2), 122-136. https://doi.org/10.1504/IJLIC.2013.052953

Kim, D. y., Kumar, V., \& Kumar, U. (2009). A framework of intellectual capital management based on ISO 9001 quality management system: the case study of ISO 9001 certified Public 
R\&D Institute. Knowledge and Process Management, 16(4), 162-173.

https://doi.org/10.1002/kpm.333

Kweh, Q. L., Lu, W.-M., \& Wang, W.-K. (2014). Dynamic efficiency: intellectual capital in the Chinese non-life insurance firms. Journal of Knowledge Management, 18(5), 937-951. https://doi.org/10.1108/JKM-06-2014-0240

Laing, G., Dunn, J., \& Hughes-Lucas, S. (2010). Applying the VAIC ${ }^{\text {TM }}$ model to Australian hotels. Journal of Intellectual Capital, 11(3), 269-283.

https://doi.org/10.1108/14691931011064545

Liang, C. J., Huang, T. T., \& Lin, W. C. (2011). Does ownership structure affect firm value? Intellectual capital across industries perspective. Journal of Intellectual Capital, 552-270. https://doi.org/10.1108/14691931111181724

Lu, Y., Tian, Z., Buitrago, G. A., Gao, S., Zhao, Y., \& Zhang, S. (2021). Intellectual capital and firm performance in the context of venture-capital syndication background in China. Complexity, 2021, 1-17. https://doi.org/10.1155/2021/9931985

Luthy, D. H. (1998). Intellectual capital and its measurement. Paper presented at the Proceedings of the Asian Pacific Interdisciplinary Research in Accounting Conference (APIRA), Osaka, Japan.

Maditinos, D., Chatzoudes, D., Tsairidis, C., \& Theriou, G. (2011). The impact of intellectual capital on firms' market value and financial performance. Journal of Intellectual Capital, 12(1), 132-151. https://doi.org/10.1108/14691931111097944

Maji, S. G., \& Goswami, M. (2016). Intellectual capital and firm performance in emerging economies: the case of India. Review of International Business and Strategy, 26(3), 410-430. https://doi.org/10.1108/RIBS-03-2015-0019

Majumder, S. C., Appiah, B. K., \& Cardorel, O. C. (2021). Determinants of market to book value and financial performance of Chinese listed firms: implication of MVAIC model. International Journal of Learning Intellectual Capital, 18(2), 131-153.

https://doi.org/10.1504/IJLIC.2021.114612

McGregor, J., Tweed, D., \& Pech, R. (2004). Human capital in the new economy: devil's bargain? Journal of Intellectual Capital, 5(1), 153-164.

https://doi.org/10.1108/14691930410512978

Mehri, M., Umar, M. S., Saeidi, P., Hekmat, R. K., \& Naslmosavi, S. (2013). Intellectual capital and firm performance of high intangible intensive industries: Malaysia evidence. Asian Social Science, 9(9), 146-155. https://doi.org/10.5539/ass.v9n9p146

Morris, C. (2015). An industry analysis of the power of human capital for corporate performance: Evidence from South Africa. South African Journal of Economic and Management Sciences, 18(4), 486-499. https://doi.org/10.4102/sajems.v18i4.1191

Nadeem, M., Gan, C., \& Nguyen, C. (2017). The importance of intellectual capital for firm 
performance: Evidence from Australia. Australian Accounting Review, 28(3), 334-344. https://doi.org/10.1111/auar.12184

Nazari, J. A., \& Herremans, I. M. (2007). Extended VAIC model: measuring intellectual capital components. Journal of Intellectual Capital, 8(4), 595-609.

https://doi.org/10.1108/14691930710830774

Nimtrakoon, S. (2015). The relationship between intellectual capital, firms' market value and financial performance: Empirical evidence from the ASEAN. Journal of Intellectual Capital, 16(3), 587-618. https://doi.org/10.1108/JIC-09-2014-0104

Pulic, A. (1998). Measuring the performance of intellectual potential in knowledge economy. Paper presented at the 2nd McMaster Word Congress on Measuring and Managing Intellectual Capital by the Austrian Team for Intellectual Potential, Hamilton.

Pulic, A. (2000). MVA and VAIC analysis of randomly selected companies from FTSE 250. Available at: www.vaic-on.net/downloads/ftse30.pdf

Pulic, A. (2004). Intellectual capital-does it create or destroy value? Measuring Business Excellence, 8(1), 62-68. https://doi.org/10.1108/13683040410524757

Pulic, A. (2008). The principles of intellectual capital effciency - A brief description. [Online] Available: http://www.cik-hr.com/data/principles_2008.pdf

Restuti, M. D., Diyanti, V., \& Shauki, E. R. (2019). Intellectual capital and firm performance: Applying a modified value-ddded coefficient. Paper presented at the 1st Asia Pacific Business and Economics Conference (APBEC 2018). https://doi.org/10.2991/apbec-18.2019.16

Riahi-Belkaoui, A. (2003). Intellectual capital and firm performance of US multinational firms: a study of the resource-based and stakeholder views. Journal of Intellectual Capital, 4(2), 215-226. https://doi.org/10.1108/14691930310472839

Roos, J., Edvinsson, L., \& Dragonetti, N. C. (1997). Intellectual capital: Navigating the new business landscape (1 ed.). UK: Macmillan. https://doi.org/10.1007/978-1-349-14494-5

Sardo, F., \& Serrasqueiro, Z. (2017). A European empirical study of the relationship between firms' intellectual capital, financial performance and market value. Journal of Intellectual Capital, 18(4), 771-788. https://doi.org/10.1108/JIC-10-2016-0105

Scafarto, V., Ricci, F., \& Scafarto, F. (2016). Intellectual capital and firm performance in the global agribusiness industry: The moderating role of human capital. Journal of Intellectual Capital, 17(3), 530-552. https://doi.org/10.1108/JIC-11-2015-0096

Sherif, M., \& Elsayed, M. (2016). The impact of intellectual capital on corporate performance: Evidence from the Egyptian insurance market. International Journal of Innovation Management, 20(03), 1650034. https://doi.org/10.1142/S1363919616500341

Siegel, S. (1988). Castellan. Nonparametric statistics for the social sciences. In: New York: McGraw-Hill. 
Singh, R. D., \& Narwal, K. P. (2015). Intellectual capital and its consequences on company performance: a study of Indian sectors. International Journal of Learning and Intellectual Capital, 12(3), 300-322. https://doi.org/10.1504/IJLIC.2015.070169

Stahle, P., Stahle, S., \& Aho, S. (2011). Value added intellectual coefficient (VAIC): a critical analysis. Journal of Intellectual Capital, 12(4), 531-551.

https://doi.org/10.1108/14691931111181715

Starovic, D., \& Marr, B. (2003). Understanding corporate value: managing and reporting intellectual capital. CIMA.

Stewart, T., A. (1991). Brainpower. Fortune. pp. 44-56.

https://doi.org/10.1007/978-1-349-11861-8_3

Stewart, T. A. (1997). Intellectual capital: The new wealth of organizations. London: Nicholas Brealey.

Sveiby, K. E. (1997). The new organizational wealth: Managing \& measuring knowledge-based assets. Berrett-Koehler Publishers.

Sydler, R., Haefliger, S., \& Pruksa, R. (2014). Measuring intellectual capital with financial figures: Can we predict firm profitability? European management journal, 32(2), 244-259. https://doi.org/10.1016/j.emj.2013.01.008

Tan, Y., Ochoa, J. J., Langston, C., \& Shen, L. (2015). An empirical study on the relationship between sustainability performance and business competitiveness of international construction contractors. Journal of Cleaner Production, 93, 273-278.

https://doi.org/10.1016/j.jclepro.2015.01.034

Tran, N. P., \& Vo, D. H. (2020). Human capital efficiency and firm performance across sectors in an emerging market. Cogent Business Management and Labour Studies, 7(1), 1738832. https://doi.org/10.1080/23311975.2020.1738832

Ulum, I., Ghozali, I., \& Purwanto, A. (2014). Intellectual capital performance of Indonesian banking sector: a modified VAIC (M-VAIC) perspective. Asian Journal of Finance \& Accounting, 6(2), 103-123. https://doi.org/10.5296/ajfa.v6i2.5246

Vargas-Hernández, J. G., \& Noruzi, M. R. (2010). How intellectual capital and learning organization can foster organizational competitiveness? International Journal of Business and Management, 5(4), 183-193. https://doi.org/10.5539/ijbm.v5n4p183

Wintoki, M. B., Linck, J. S., \& Netter, J. M. (2012). Endogeneity and the dynamics of internal corporate governance. Journal of Financial Economics, 105(3), 581-606.

https://doi.org/10.1016/j.jfineco.2012.03.005

Wisner, J. D., \& Eakins, S. G. (1994). A performance assessment of the US Baldrige Quality Award winners. International Journal of Quality \& Reliability Management, 11(2), 8-25. https://doi.org/10.1108/02656719410051643

Wooldridge, J. M. (2015). Introductory econometrics: A modern approach: Cengage learning. 
Wu, Y. C. J., \& Chou, Y. H. (2007). A new look at logistics business performance: intellectual capital perspective. The International Journal of Logistics Management, 18(1), 41-63. https://doi.org/10.1108/09574090710748162

$\mathrm{Xu}$, J., \& Li, J. (2020). The interrelationship between intellectual capital and firm performance: evidence from China's manufacturing sector. Journal of Intellectual Capital. https://doi.org/10.1108/JIC-08-2019-0189

Yalama, A. (2013). The relationship between intellectual capital and banking performance in Turkey: evidence from panel data. International Journal of Learning and Intellectual Capital, 10(1), 71-87. https://doi.org/10.1504/IJLIC.2013.052079

Yu, H.-C., Wang, W.-Y., \& Chang, C. (2015). The stock market valuation of intellectual capital in the IT industry. Review of Quantitative Finance and Accounting, 45(2), 279-304. https://doi.org/10.1007/s11156-014-0437-5

Zéghal, D., \& Maaloul, A. (2010). Analysing value added as an indicator of intellectual capital and its consequences on company performance. Journal of Intellectual Capital, 11(1), 39-60. https://doi.org/10.1108/14691931011013325

\section{Copyright Disclaimer}

Copyright for this article is retained by the author(s), with first publication rights granted to the journal.

This is an open-access article distributed under the terms and conditions of the Creative Commons Attribution license (http://creativecommons.org/licenses/by/4.0/). 